\title{
Economic growth of airlines industry: An overview of domestic airlines in Bangladesh
}

\author{
Sharmin Sultana \\ Lecturer, Business Administration, Southern University Bangladesh, Bangladesh
}

Corresponding Author:

Email: sharmin.sunny53@gmail.com

\begin{abstract}
According to International Air Transport Association (IATA), the aviation industry supports tourism and international business by providing the world's only rapid worldwide transportation network. Airlines transported 2.8 billion passengers and 47.6 million metric tons of air cargo in 2011, connecting the world's cities with 36,000 routes. By providing these services, the aviation industry plays an important role in enabling economic growth and providing various economic and social benefits. (The Travel \& Tourism Competitiveness Report 2013). In Bangladesh the role of domestic airlines are increasing economically and socially. Basically, secondary data are used and four main domestic airlines are considered as the sample. The paper focused on the history of aviation industry in Bangladesh, the overview of domestic airlines and the current trend. The paper is concluded with some policy recommendations to further development of the airlines industry in Bangladesh.
\end{abstract}

Keywords: Domestic airlines, Economic growth, Bangladesh.

\section{Introduction}

Today's airline industry exists in an intensely competitive market. As per data available from the information centre of The World Bank, during 2012 approximately 2.8 billion people traveled using air transportation. The global airlines industry is expected to reach an estimated $\$ 832.8$ billion in 2020 with a CAGR of $3.7 \%$ over the next seven years (2013-2020). The global airline industry comprises air transport service providers of passenger and cargo. Industry services are used by individuals and business for international, domestic, and regional travel purposes across the world. (JCR-VIS Credit Rating Company Limited 2013)

Air transport has always been considered as a very special sector in the international context. It facilitates global economic and social growth, international and domestic tourism, world trade growth (Hardy, F. W. 2009).

The domestic air transportation network in Bangladesh is comprised of 8 conventional (full-size) airports, 8 airports for STOL (Short-Take-Off and Landing) aircraft including two airports under construction. The 8 conventional airports, which are used for commercial purpose, handle widely varying traffic volumes. The largest airport is Zia International airport near Dhaka and the smallest one is Cox's Bazar airport. The most important corridors, as measured by air passenger volumes, are those between Dhaka, at one end, and Chittagong, Jessore, Sylhet at the other end. (M.J.B. Alam, and M.M. Hoque).

In Bangladesh, there are few domestic airlines which are operating flights both nationally and internationally. The demands of these airlines were low before due to high price. But now the price is getting down due to high supply, low operating cost, customer service, safety and time. Some private companies are dominating the market currently than Biman Bangladesh Airlines.

\section{Literature review}

Air transport industry plays an important role in the economy of any country today. Aviation industry has the power to increase national income, employment and tax revenues with its various extensions such as airline companies, airports, ground services and aircraft manufacturers (Oxford Economics, 2014: 7).

Aviation demand is affected by many factors which interact with each other. It can be said that in general economic factors affect the demand for air transport. Income levels and product prices are the most influencing factors for demand. The higher is the income, the higher is the demand for further travel. If income decreases, people give up these kinds of needs that they think as luxury (Doganis, 2010: 200).

Because it acts as a catalyst for economic activities of air transport, the sector is vital for any country's economy. As well as supporting international, regional and local prosperity and economic growth, it increases the quality of life serving many different purposes such as business, education, health, social activities (Baikgaki and Daw, 2013: 389). Therefore, air transport is very important as it affects people's living and working conditions, their relations with other nations and daily life - economically, socially and politically (Kane, 2007: 5).

Nisa Secilmis and Aylin Koc (2016) discovered that, national income per capita and industrial production index have positive impact on aviation demand, while ticket prices, inflation and exchange rate have a negative impact on it. 
M. Marazzo et al. (2010) analyzed the correlation between aviation demand (passenger-km: PAX) and GDP for Brazil.

H. Zhang and M. Zhu (2011) studied the relation between air transportation (total turnover of air transport) and GDP in China for the years of 19902009 by using a causality test.

S. Sun and Y. Li (2011) analyzed the correlation between the development of air transport industry and economic growth, and the contribution to economic growth in China for the years since 1978 till 2009.

B. Mehmood and K. Kiani (2013) tested the relationship between aviation and economic growth using the data from 1973 to 2013 by using causality analysis for Pakistan data.

B. Mehmood et al. (2013) researched the interaction between aviation demand (passengers carried by air transport-PC) and economic growth (current LCU-GDP) in India, 1970 to 2012.

According to B. Mehmood at al. (2014) in the long run there is a co-integration equation between aviation demand (PAX) and economic growth in Romania for the years from 1970 to 2012 and this situation holds in the short run. Granger causality exists running from PAX to GDP, but does not exist from GDP to PAX.

B. Mehmood and A. Shahid (2014) used cointegration and causality analyses to estimate the relationship between aviation demand (passengers carried by air transport: PAX) and economic growth (GDP) in Czech Republic, 1970-2012.

B. Mehmood et al. (2014) has revealed the relationship between aviation demand and economic growth for Bangladesh with the data covering 19732012. By using fully modified OLS, dynamic OLS and conical co integration tests, they revealed a relationship between aviation demands. And economic growth, and by using Granger causality test they show that the direction of causal relationship is from GDP to PAX.

Y. Hu et al. (2015) investigated domestic air passenger traffic (APT) and real economic growth in China by using heterogeneous panel models for the time span of 2006Q1-2012Q3.

M.J.B. Alam, and M.M. Hoque studied that, the supply cost of the private airlines in Bangladesh is 40 percent lower than the same for public airlines. The results of this study can be used by the South and Southeast Asian countries to develop policies in this regard.

K Rahman, S Azad, and S Mostari (2015), drawn a clear picture of the types of competitive advantage and how these advantages can be achieved and sustained through adopting generic strategies.

Md. Jobair and Dewan (1998), developed some models of infrastructure development and service improvement of domestic air transportation in the country.

\section{Rational of the study}

Air transport has always been considered as a very special sector in the international context. It facilitates global economic and social growth, international and domestic tourism, world trade growth (Hardy, 2009).

The researcher tries to evaluate the trend and growth of domestic airlines which can contribute largely in GDP in future.

\section{Research Objectives}

The specific objectives are:

1. To know about the historical background of the aviation industry in Bangladesh.

2. To show the current trend of domestic airlines in Bangladesh.

3. To find out the problems and provide recommendations for the betterment of domestic airlines in Bangladesh.

\section{Research Design \\ Sample size}

Random sampling method is used in this study. Four main domestic airlines are chosen as sample:

1. Biman Bangladesh Airlines

2. Regent Airways

3. Novo Air

4. U S Bangla

\section{Sources of data}

Secondary sources of data from various websites, research articles and books, IATA Annual Review 2016, ministry of Civil Aviation and Tourism, CAAB and Bangladesh Bureau of Statistics.

\section{Aviation industry in Bangladesh}

In August1943, a South Asia Command was formed under Admiral Mountbatten, including the RAF Third Tactical Air Force (Third TAF), which launched the second Burma Campaign against the Empire of Japan in the December that year. The Royal Indian Airforce (RIAF), Indian part of the Royal Air Force played a crucial role by providing tactical reconnaissance and extensive close support to the army when a British Corps started advancing down the Arakan coast in January 1944.

In November 1943, 6 Squadron and later 8Squadron were moved to Cox's Bazaar. By the end of February1944, No. 6 Squadron pilots had completed over 1,000 operational sorties, averaging 6 sorties a day per pilot, are cord for the entire the Third TAF. Towards the end of March 1944, 4 Squadron joined the operations when it was moved first to Feni airfield, and then to Comilla in June to replace 6Squadron.

The Shahjalal International Airport originated in 1941, during the Second world war, as the British government built a landing strip at Kurmitola, several kilometers north of Tejgaon, as an extra landing strip for the Tejgaon Airport. At that time Tejgaon was a 
military airport, to operate warplanes towards the war fields of Kohima (Assam) and Burmese war theatres. Shah Amanat International Airport was a Combatair field as well as a supply point and photographic reconnaissance base by the United States Army Air Forces Tenth Air Force during the Burma Campaign 1944-1945. Known American units assigned to Chittagong were: $80^{\text {th }}$ Fighter Group, flew P 38 Lightning fighters over Burma between March 1944 and February 1945; $8^{\text {th }}$ Reconnaissance Group, between October and December 1944 (various detachments); and $4^{\text {th }}$ Combat Cargo Group, flew C-46 Commando transports between January and June1945.Osmani International Airport in Sylhet was built during British rule as Sylhet Civil Airport, partly to check Japanese aggression from Burma. Biman Bangladesh Airlines earns most of its revenue from this airport.

During the 1971 Liberation War of Bangladesh Indian Air Force (IAF) and the Pakistan Air Force (PAF) fought had extensive engagements in the sky over Bangladesh. The first engagement was on 22 November over the Salient of Boy rain West Bengal .In the process Tejgaon Airport suffered extensive damage.

Then, on the night of 3 December 1971, Canberra bombers of Eastern Air Command struck Tejgaon, which was guarded by PAF No.14 Squadron equipped with Sabre jets which lacked night fighting capability. By the morning of 4 December, strike missions against Tejgaon were assigned to 11 IAF squadrons, including Hunters of the No.7 Squadron, No.14 Squadron, No.17 Squadron and No.37 Squadron of IAF, as well as Su-7s of No.221 Squadron and MiG-21s of No.28 Squadron.

Throughout 4 and 5 December, IAF concentrated in attacking the aircraft on the ground. But, it failed to cause significant damage to the PAF assets in welldispersed and camouflaged locations. By the evening of 5 December, the IAF changed tactics. On the morning of 6 December four MiG-21s (No.28Sqn), flying from Gauhatihit Tejgaon with 1000 lber, scoring several hits on the runway. Kurmitola was attacked on the morning of 7 December, when Mig-21s of No.28 Sqn again hit the runway.No.7 Sqn was pulled out of the eastern ops on the 6 December to help the Indian Army in the west. Repeated attack by MiG-21sand Hunters of No.14 and No.28 however, kept the runway cratered. The IAF assault effectively grounded the PAF by 7 December, and No.14 Squadron was taken out of the war. The IAF also bombed other air fields including the abandoned WWII airfields of Comilla, Lalmanirhat and Shamsher Nagar through the war, denying their use to PAF.

On August 20, 1971 Flight Lieutenant Matiur Rahman attempted to pilotaT-33 trainer from Karachi, Pakistan to Indian order to defect from the Pakistan Air Force and join the liberation movement of Bangladesh. However, Matiur could not take the plane out of Pakistani territory, as reportedly, Pilot Officer Rashid Minhas, the other pilot in the plane, forced it to crash in Thatta, a place near the Indian border. Matiur was awarded Bir Sreshtho and Minhas was awarded Nishan - E Haider, respectively the highest military honors in Bangladesh and Pakistan, and both has air bases named after them, respectively in Jessore and Kamra.

Modern aviation in modern Bangladesh are a began when the British Government of India built a Royal Indian military air strip in Tejgaon during World War II to fly war planes towards the battlefields of Kohima and war theaters in Burma. Other air strips were builtin Comilla, Feni, Chittagong, Cox's Bazar, Chakaria, Sylhet, Jessore, Rajshahi and Lalmonirhat.

(source: https://www.biman-airlines.com/about/history)

\section{Biman Bangladesh Airlines}

Biman Bangladesh Airlines is the government airline of Bangladesh. Its main hub is at Shahjalal International Airport in Dhaka, and also operates flights from Shah Amanat International Airport in Chittagong, Shahjalal International Airport in Dhaka and Osmani International Airport in Sylhet. BIMAN is the largest but is still a relatively small carrier, operating 10 aircraft (all jets) to 19 international and three domestic destinations. Biman Bangladesh Airlines was established on 4 January 1972 as Bangladesh's national airline under the Bangladesh Biman Ordinance. It has air service agreements with 42 countries \& currently flies to 16 different countries. Bimaan is the largest but is still a relatively small carrier, operating 10 aircraft (all jets) to nineteen international and three domestic destinations. Biman Bangladesh Airlines, popularly known as Biman, is the national airlines of Bangladesh. A member of IATA, it flies passengers and cargo to 18 international destinations in Asia and Europe.

(Source:https://www.biman-airlines.com/about)

Biman came into being on January 04, 1972 with a gift of DC-3 aircraft from Bangladesh Air force. Presently Biman has four 777-300ER, two 777-200ER, two 737800 , and two A310-300 in its fleet. Biman does entire maintenance work on its F-28 aircraft. Biman is also doing C-check, D-check on DC10-30 and A310-300 in its hangar complex at Dhaka. Checks, repair and maintenance of one DC1030, one wide bodied Boeing and two F-28 aircraft can be done simultaneously there. In addition to its own aircraft, Biman's ground-handling unit also provides support to Singapore Airlines, Thai Airways, Malaysia Airlines, Qatar Airways, Emirates, Kuwait Airways, Oman Air, Saudia, Gulf Air, PIA, Indian Airlines, Dragon Air, Druk Air, etc.at Hazrat Shahjalal International Airport, Dhaka. Biman Flight Catering Center (BFCC) has the capacity of producing 8500 meals a day and is providing cuisine not only to Biman but also to Saudia, Etihad, Malaysia Airlines, Thai Airways, Emirates, Dragon Air and China Southern Airlines.

(Source:https://www.biman-airlines.com/corporate) 
Domestic destinations: Barisal, Chittagong, Cox's Bazaar, Dhaka, Sylhet, Saidpur, Rajshahi, Jessore

International destinations: Abu Dhabi, Bahrain, Doha, Dubai, Jeddah, Kuwait, Muscat, Riyad, Bangkok, Kuala Lumpur, Singapore, London, Katmandu, Kolkata, Yangon

\section{Regent Airways}

Regent Airways launched in late 2010 and added international services in mid-2013. It currently serves three domestic and four international destinations with a fleet of five aircraft (two jets and three turboprops).

Domestic Destinations: Dhaka-Chittagong-Cox'sbazar International Destinations: Muscot, Kathmandu, Doha, Kualalampur, Colombo, Bangkok and Singapore. Package destinations: Cox's bazar, Nepal, Thailand, Malaysia and Singapore.

Regent Airways (incorporated as HG Aviation Limited) is a wholly-owned subsidiary of Habib Group - the Chittagong-based conglomerate engaged in a diverse portfolio of business endeavors which include power, steel, readymade garments, textiles, spinning, cement, paper and fertilizer among others.

The airline began commercial flight operations since 10 November, 2010 using its own fleet of two Canadian-built Bombardier Dash-8-Q300 aircraft, each seating 50 passengers in a single-class layout. The aircraft is known for its exceptional reliability and passenger comfort.

Their fleet consists of 08 (eight) aircrafts. Among those 02 (two) Dash-8-Q300 aircraft reputed for its exceptional reliability and passenger comfort, which are maintained to European standards, 02 (two) Boeing 737-700 and 04 (four) Boeing 737-800 Next Generation aircraft which was awarded type certification by the FAA, In addition, the newer 737 models offer a modern flight deck using the most advanced navigation technology available today. The fleet is planning to expand soon with larger jet aircraft as Regent is expanding more international destinations reaching beyond the borders of Bangladesh. With the tagline "every little thing counts", Regent Airways reasserts its commitment to excel in airline service and be recognized as a world-class airline from Bangladesh.

It is also noteworthy that Regent Airways is the first airline from Bangladesh to have received approval for its Safety Management System Manual from the Civil Aviation Authority of Bangladesh (CAAB) which is an internationally acknowledged standard set forth by the International Civil Aviation Organization (ICAO). Across the fleet and for every single flight, Regent is giving paramount importance to the safety of its passengers. Regent is closely working with the International Air Transport Association (IATA) global airline industry leading organization, which trains the airline staff in the areas of safety, security, and customer service. Regent Airways has also planned to develop the country's first full-fledged maintenance hangar belonging to a private airline. Regent Airways is becoming the most-preferred airline for the passengers to fly with. They have proved an on-time performance of over $97 \%$ and have carried over 783,240 passengers within three years of operations with a perfect safety record.

(Source:

http://www.flyregent.com/pages/15/About\%20Us)

\section{Novo air}

NOVOAIR is the premium brand private airline in Bangladesh started domestic flight operations in January 2013. They serve our esteemed passengers with one motto - "The Art of Aviation". Within 3 years, NOVOAIR established as a Premium Scheduled Passenger Airline spreading wings in all domestic and amazing regional destinations. With a fleet of EMB-145 Jet and superb ATR 72-500 aircrafts, combined with superior on-time performance, great comfort and excellent safety record, NOVOAIR achieved the honor of "Best Domestic Airline" adjudged by "Monitor Airline of the Year". NOVOAIR has a host of professionals to support your need including air charter, air cargo transportation and travel \& holiday services. They take a great deal of pride in providing services to our clients with safety, reliability, cost effectiveness and dedication. The service ethics evolves with "You first" and therefore, await to listen from you. (source: https://flynovoair.com/index.php/about)

Novo air launched in early 2013 and currently operates three regional jets to five domestic destinations. It recently secured approval to operate overseas routes and aims to launch international services by the end of 2014

Domestic destinations: Dhaka-Chittagong-Cox'sbazarSylhet-Syedpur

International destinations: Kolkata.

Future destinations: Riyad, Jeddah, Dubai, Muscot, Kathmandu, Guwahati, Male, Kualalampur, Colombo, Bangkok, Singapore, Guangzhou.

Holiday packages: Cox’s Bazaar, Kolkata

\section{US-Bangla Airlines}

The US-Bangla Airlines (USBA) Ltd is a dream project of US-Bangla Group- a leading business conglomerate of Bangladesh. The USBA acquired initially two Bombardier built DASH 8-Q400 aircraft. The 3rd DASH 8-Q400 aircraft was acquired and was 26 June 2015. These are 76-seat high speed propeller aircraft which can fly at jet speed of 667 kilometers per hour. In fact it is the fastest propeller airlines aircraft and also one of the safest airlines with no record of any fatal accident.

US-Bangla Airlines started its journey on 17 July 2014 with motto Fly Fast Fly Safe. Amongst all the domestic airlines, currently we are operating maximum 
number of flights, transported maximum number of passengers which is about $50 \%$ of the total domestic traffic, to maximum number of seven destinations. From 17 July 2014 till 30 Nov 2014, the USBA has conducted flights on 8138 sectors and carried 5, 11, 106 passengers which is about $50 \%$ of the total domestic traffic. Currently, US-Bangla Airlines operates four Boeing 737-800 aircraft and three Dash 8 - Q400 aircraft.

1. The USBA has been adjudged as "The Best Domestic Airlines" - for the year 2014 \& 2015 by Bangladesh Travelers Forum.

2. They are the only Airlines to receive the ISO 9001:2008 Certification which conforms to Universal Safety Oversight Audit Program.

3. It has also been audited and certified by the Chevron Company for their officials.

4. The Airline's aircraft are being maintained by qualified and highly experienced foreign and local Aircraft Maintenance engineers.

5. Their pilots are also highly professional and experienced.

(Source:

banglaairlines.com/welcome/about_us)
Domestic destinations: Dhaka-Chittagong-Cox's Bazar- Jessore-Barisal-Saidpur-Rajshahi.

International destinations: Doha, Kolkata, Bangkok, Kualalumpur, Singapore, Kathmandu, Muscot

Holiday packages: Cox's Bazar, Chittagong, Barisal, Rajshahi, Sylhet, Kualalumpur, Bangkok, Singapore, Kathmandu, Kolkata.

\section{Airline contribution Bangladesh economy}

Civil Aviation Authority, Bangladesh (CAAB) calculated, the combined annual market size of 2014 was worth USD 440 million, with 5.8million passengers and 2.3 lakh tons of cargo. As we can observe, there is a positive correlation of the passenger growth rate with the GDP growth rate. This is because of three broad reasons:

A higher GDP equates to higher purchasing power, which incentivizes many to choose air travel within the country as an alternative to trains and buses. Given that the business environment is growing quite rapidly, saving time is quite crucial.

Airplanes save atleast70\% of a business executive's travel time. A higher GDP of ten means Higher FDI. Foreign nationals tend to choose air travel over other means of transport.

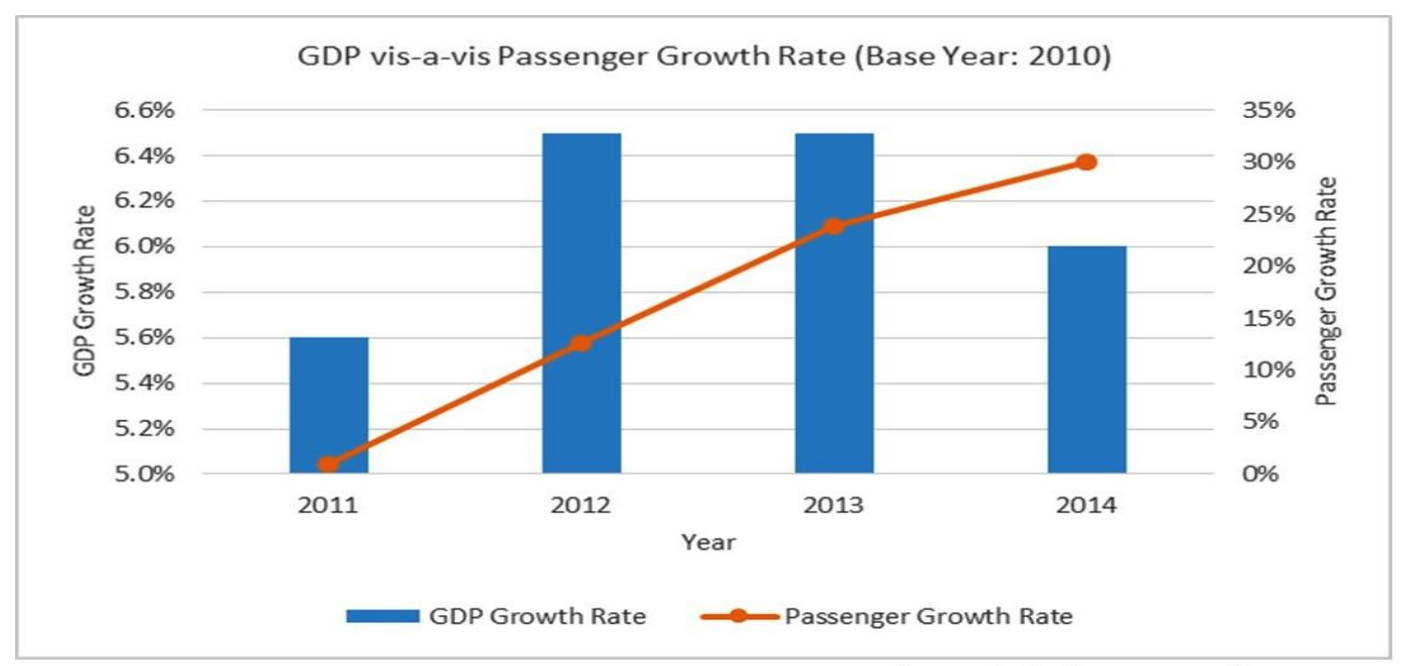

Source: $C A A B$ and Bangladesh Bureau of Statistics

Fig. 1

As we can observe, there is a positive correlation of the passenger growth rate with the GDP growth rate. This is because of three broad reasons:

1. A higher GDP equates to higher purchasing power, which incentivizes many to choose air travel within the country as an alternative to trains and buses.

2. Given that the business environment is growing quite rapidly, saving time is quite crucial. Airplanes save at least $70 \%$ of a business executive's travel time.

3. A higher GDP often means higher FDI. Foreign nationals tend to choose air travel over other means of transport. 
Table 1: Domestic skies: Scheduled air capacity in Bangladesh (non-stop departures; 2013)

\begin{tabular}{|c|l|c|c|c|}
\hline Rank & \multicolumn{1}{|c|}{ Airline } & Available Seats & \% Share & \% Change v 2012 \\
\hline 1 & United Airways (4H) & 388,115 & $31.7 \%$ & $18.6 \%$ \\
\hline 2 & $\begin{array}{l}\text { Biman Bangladesh } \\
\text { Airlines (BG) }\end{array}$ & 377,743 & $30.9 \%$ & $(-43.9) \%$ \\
\hline 3 & Regent Airways (RX) & 349,092 & $28.5 \%$ & $(-1.9) \%$ \\
\hline 4 & NovoAir (VQ) & 108,930 & $8.9 \%$ & New Entrant \\
\hline \multicolumn{2}{|c|}{ Total } & $1,223,880$ & - & $(-13.2) \%$ \\
\hline
\end{tabular}

(Source: http://www.routesonline.com/news/29/breaking-news/242682/domestic-skies-air-capacity-in-bangladesh/)

Table 2: Domestic air capacity in Bangladesh (non-stop weekly departures)

\begin{tabular}{|c|l|c|c|c|}
\hline Rank & \multicolumn{1}{|c|}{ Airport } & $\begin{array}{c}\text { Weekly } \\
\text { Departures }\end{array}$ & $\begin{array}{c}\text { Weekly } \\
\text { Seats }\end{array}$ & \% Capacity \\
\hline 1 & Dhaka Zia International (DAC) & 175 & 13,887 & $46.8 \%$ \\
\hline 2 & Chittagong Patenga (CGP) & 103 & 8,996 & $30.3 \%$ \\
\hline 3 & $\begin{array}{l}\text { Sylhet Osmani International } \\
\text { (ZYL) }\end{array}$ & 27 & 4,127 & $13.9 \%$ \\
\hline 4 & Cox's Bazar (CXB) & 24 & 1,179 & $4.0 \%$ \\
\hline 5 & Jessore (JSR) & 28 & 1,148 & $3.9 \%$ \\
\hline (Others) & 8 & 328 & $1.1 \%$ \\
\hline \multicolumn{2}{|l|}{ Total } & 365 & 29,665 & - \\
\hline
\end{tabular}

(Source: http://www.routesonline.com/news/29/breaking-news/242682/domestic-skies-air-capacity-in-bangladesh/)

Table 3: Domestic skies: Scheduled air capacity in Bangladesh (non-stop departures; 2013)

\begin{tabular}{|c|l|c|c|c|}
\hline Rank & \multicolumn{1}{|c|}{ Airport } & Available Seats & \% Share & \% Change v 2012 \\
\hline 1 & Dhaka (DAC) & 587,156 & $48.0 \%$ & $(-11.5) \%$ \\
\hline 2 & Chittagong (CGP) & 381,317 & $31.2 \%$ & $(-8.4) \%$ \\
\hline 3 & Sylhet (ZYL) & 102,985 & $8.4 \%$ & $(-43.7) \%$ \\
\hline 4 & Jessore (JSR) & 84,750 & $6.9 \%$ & $11.3 \%$ \\
\hline 5 & Cox's Bazar (CXB) & 46,395 & $3.8 \%$ & $(-12.4) \%$ \\
\hline 6 & Saidpur (SPD) & 9,918 & $0.8 \%$ & $(-0.8) \%$ \\
\hline 7 & Rajshahi (RJH) & 6,959 & $0.6 \%$ & $(-7.8) \%$ \\
\hline 8 & Barisal (BZL) & 3,697 & $0.3 \%$ & New Entrant \\
\hline 9 & Ishurdi (IRD) & 703 & $0.1 \%$ & New Entrant \\
\hline Total & & $1,223,880$ & - & $(-13.2) \%$ \\
\hline
\end{tabular}

(Source: http://www.routesonline.com/news/29/breaking-news/242682/domestic-skies-air-capacity-in-bangladesh/)

Table 4: International air capacity from Bangladesh (non-stop weekly departures)

\begin{tabular}{|c|l|c|c|c|}
\hline Rank & \multicolumn{1}{|c|}{ Airline } & $\begin{array}{c}\text { Weekly } \\
\text { Flights }\end{array}$ & $\begin{array}{c}\text { Weekly } \\
\text { Seats }\end{array}$ & \% Capacity \\
\hline 1 & Biman Bangladesh Airlines (BG) & 73 & 16,640 & $26.5 \%$ \\
\hline 2 & Emirates Airline (EK) & 17 & 5,061 & $8.0 \%$ \\
\hline 3 & Jet Airways (9W) & 21 & 3,360 & $5.3 \%$ \\
\hline 4 & Saudi Arabian Airlines (SV) & 10 & 2,980 & $4.7 \%$ \\
\hline 5 & Qatar Airways (QR) & 11 & 2,933 & $4.7 \%$ \\
\hline 6 & Air Arabia (G9) & 17 & 2,754 & $4.4 \%$ \\
\hline 7 & United Airways (4H) & 22 & 2,637 & $4.2 \%$ \\
\hline 8 & Dragonair (KA) & 9 & 2,610 & $4.2 \%$ \\
\hline 9 & Thai Airways International (TG) & 7 & 2,506 & $4.0 \%$ \\
\hline 10 & Flydubai (FZ) & 14 & 2,240 & $3.6 \%$ \\
\hline (Others) & 111 & 19,170 & $30.5 \%$ \\
\hline Total & 312 & 62,891 & - \\
\hline
\end{tabular}

\section{Problems}

High Fare: The fares of airlines are higher than trains and buses. So, it is unaffordable for many people to take a domestic tour from one city to another in our country. The fare of U S Bangla and Novo air are quite higher than Biman Bangladesh and Regent Airways. 
Customer Service: The on-board service of employees, employee behavior, body language sometimes becomes one of the determining factors of selecting air carrier. So, employee should focus on these.

Security: The main sensitive factor in airline is security. Sometimes staffs don't check passengers properly or many unchecked pedestrians roam around the airport.

Time management: Lack of time management is experienced by passengers due to bad weather, unavailability of air craft on time, less number of staffs in aircraft are the reasons of this timing problem.

Airport capacity: In Bangladesh, the main airport is Hazrat Shahjalal International Airport. Other airports are not that much well equipped and well maintained. The capacity to takeoff and landing many international flights are unavailable in Chittagong, Cox's Bazar or other airports.

Problem in low demand routes: There are some routes which are not much popular or demanding like Dhaka-Chittagong-Dhaka or Dhaka-Cox'z BazarDhaka. So, the airlines companies face low profit in some low demand routes but they have to bear the fixed cost.

Training: The employees of respective carriers, the staffs at airport counters all are should be trained properly in dealing with customer at any situation. Sometimes due to customer behavior or less responsiveness can reduce the number of passengers of respective airline.

\section{Recommendations}

Development of long term plan: Many airlines don't have long tern plans or strategy for future development. Airline industry requires capital, long term strategies to sustain in the market.

Infrastructural development: The airports should be better equipped, spacious; more developed with all more facilities so that other airports than Hazrat Shahjalal International Airport can be used for international service.

Availability of modern aircraft: More modern and large aircraft should be imported from developed countries. There are some old aircrafts are still in use which are not healthy and safe.

Better customer service: The employees of airlines should be educated in hospitality management and more trained up in dealing customer complaints or providing customer service. Better service can enhance the performance of specific airline as well as its number of passengers.

Safety and security: Safety and security are the key issue for any passengers. Safe aircraft and safe airport should be ensured for passengers.

Low fare: The price of airlines should be reduced for the customers. Specially, on special routes where the demands are high customers prefer low fare rate than high rates airlines.

Promotional offers or frequent flyer packages: To meet the current demand and to meet competitive situation, the airline companies can offer some promotional offers on special occasion like Eid, New Year, Bangla New Year and Victory Day etc. Some airlines offer frequent flyer packages sometimes. This practice should be increased to get more customers.

\subsection{On-time performance}

People usually prefer airline than any other transport because of fastness. People want to reach a destination quickly by airline. So, airline companies should maintain the time schedule properly.

\section{Conclusion}

Aviation industry is a demanding industry now-adays. As tourism industry is growing, the importance of airlines is also growing. It's one of the sectors of tourism industry too. This paper has examined the recent economic growth and current capacity of domestic airlines industry in Bangladesh. It has also identified some problems regarding airlines industry in Bangladesh and provides some recommendations to overcome those. There were very few literature on this topic so there is further good research scope on the domestic airlines demand analysis and key selecting criteria's in domestic airlines in Bangladesh.

\section{References}

1. Atiur, Chowdhury et al. (2012) Sustainability and Growth of Low Cost Airlines: An Industry Analysis in Global Perspective; American Journal of Business and Management Vol. 1, No. 3, 2012,162-71.

2. Baikgaki, A., Daw, D. (2013). The Determinants of Domestic Air Passenger Demand in the Republic of South Africa. Mediterranean Journal of Social Sciences, 4(13):389-96.

3. Doganis, R. (2010). Flying Off Course. 4th ed. Taylor\&Francis e-Library. London and New York.

4. Hardy, F.W., (2009). Air Arabia, the world's most profitable airline: The low cost model that outperforms other discount and legacy airlines. Retrieved 16 Sep 2009 from:

http://airplanes.suite101.com/article.cfm/air_arabia_the_ worl ds_most_profitable_airline

5. Hu, Y., Xiao, J., Deng, Y., Xiao, Y., Shouyang, W. (2015). Domestic Air Passenger Traffic and Economic Growth in China: Evidence from Heterogeneous Panel Models. Journal of Air Transport Management, 42:95100.

6. IATA Air passenger market analysis JCR-VIS Credit Rating Company Limited (November 2013)

7. "Airline Industry the main drivers of future air traffic and fleet growth would be the emerging economies like Pakistan with a growing level of first time flyers..."

8. Khadiza Rahman, Sumi Azad, and Sabnam Mostari, A Competitive Analysis of Airline Industry: A Case Study on Biman Bangladesh Airlines; IOSR Journal of Business and Management (IOSR-JBM) e-ISSN: 2278-487X, p- 
ISSN: 2319-7668. Volume 17, Issue 4.Ver. II (Apr. 2015), PP 23-33 www.iosrjournals.org

9. M.J.B. Alam, and M.M. Hoque; "POTENTIAL OF PRIVATIZATION OF DOMESTIC AIR TRANSPORTATION IN BANGLADESH'

10. Marazzo, M., Scherre, R., Fernandes, E. (2010). Air transport demand and economic growth in Brazil: A time series analysis. Transportation Research Part E, 46:2619 .

11. Mehmood, B., Feliceo, A., Shahid, A. (2014). What Causes What? Aviation Demand and Economic Growth in Romania: Cointegration Estimation and Causality Analysis. Romanian Economic Business Review, 9(1):21-33.

12. Mehmood, B., Kiani, K. (2013). An Inquiry into Nexus between Demand for Aviation and Economic Growth in Pakistan. An International Multidisciplinary Research Journal, 3(10):200-11.

13. Mehmood, B., Shahid, A. (2014). Aviation Demand and Economic Growth in the Czech Republic: Cointegration Estimation and Causality Analysis. Statistica, 94(1):5463.

14. Mehmood, B., Shahid, A., Younas, I. (2013). Interdepencies between Aviation Demand and Economic Growth in India. Economic Affairs, 58(4):337-47.

15. Mehmood, B., Younas, I.Z., Shahid, A. (2014). Aviation Demand as Covariate of Economic Growth in Bangladesh: Cointegration Estimation and Causality Analysis. International Journal of Economics and Empirical Research, 2(8): 301-7.

16. Md. Jobair and Dewan (1998), Journal of Civil Engineering, The Institution of Engineers, Bangladesh, Vol. CE 26, No. 1

17. Nisa Secilmis and Aylin Koc (2016) "Economic factors affecting aviation demand: Practice of EU Countries" actual problems of economiics \#5((179)), 2016

18. Oxford Economics (2014). Economic Benefits from Air Transport in the UK. UK Country Report.

19. Sun, S., Li, Y. (2011). An Empirical Analysis on Influence of Air Transport Development to Chinese Economic Growth. International Conference on EBusiness and E-Government - ICEE, 6-8 May (pp. 1-4). Shanghai, China

20. JULIE PEROVIC; International Air Transport Association (IATA) The Travel \& Tourism Competitiveness Report 2013 |

21. Zhang, H., Zhu, M. (2011). An Empirical Research on the Relation between the Air Transportation and Economic Growth. International Conference on Management Science \& Engineering (18th),13-5.

22. September 2011. Rome, Italy.

23. http://airplanes.suite101.com/article.cfm/air_arabia_the_ worl ds_most_profitable airline

24. http://www.routesonline.com/news/29/breakingnews/242682/domestic-skies-air-capacity-in-bangladesh/

25. Co-author: Sazzad Hossain, AVP and Taosif Amin Khan, Junior Associate at Light Castle Partners

26. Do you want consumer/market data on your preferred sector? Please fill out the form and we'll get back:

27. https://docs.google.com/a/lightcastlebd.com/forms/d/1slIcBYHc7BXTWOgXK-

LL_DU8BkTS73cXEdyaRF4rTo/formResponse

28. http://www.lightcastlebd.com/blog/2015/03/marketinsight-domestic-aviation-industry-bangladesh-part-1

29. http://www.flyregent.com/

30. http://www.flyregent.com/pages/15/About\%20Us

31. https://www.biman-airlines.com/

32. https://www.biman-airlines.com/about/history
33. https://www.biman-airlines.com/corporate

34. https://flynovoair.com/

35. https://flynovoair.com/index.php/about

36. https://us-banglaairlines.com/welcome

37. https://us-banglaairlines.com/welcome/about_us

38. http://www.routesonline.com/news/29/breakingnews/242682/domestic-skies-air-capacity-in-bangladesh/ 